University of Louisville

ThinkIR: The University of Louisville's Institutional Repository

Electronic Theses and Dissertations

$5-2007$

\title{
The unseen : one actor's journey from the mind to the stage.
}

James Patrick Cronin 1982-

University of Louisville

Follow this and additional works at: https://ir.library.louisville.edu/etd

\section{Recommended Citation}

Cronin, James Patrick 1982-, "The unseen : one actor's journey from the mind to the stage." (2007). Electronic Theses and Dissertations. Paper 293.

https://doi.org/10.18297/etd/293

This Master's Thesis is brought to you for free and open access by ThinkIR: The University of Louisville's Institutional Repository. It has been accepted for inclusion in Electronic Theses and Dissertations by an authorized administrator of ThinkIR: The University of Louisville's Institutional Repository. This title appears here courtesy of the author, who has retained all other copyrights. For more information, please contact thinkir@louisville.edu. 
THE UNSEEN:

ONE ACTOR'S JOURNEY FROM THE MIND TO THE STAGE

\author{
By \\ James Patrick Cronin \\ B.S., East Tennessee State University, 2004
}

\begin{abstract}
A Thesis
Submitted to the Faculty of the

Graduate School of the University of Louisville

In Partial Fulfillment of the Requirements

For the Degree of
\end{abstract}

Master of Fine Arts

Department of Theatre Arts

University of Louisville

Louisville, KY

May 2007 
Copyright 2007 by James Patrick Cronin

All rights reserved 
THE UNSEEN:

One Actor's Journey from the Mind to the Stage

By

James Patrick Cronin

B.S., East Tennessee State University, 2004

A Thesis Approved on

April 10, 2007

By the following Thesis Committee:

Thesis Director, Dr. Russell Vandenbroucke

Mr. James Tompkins

Dr. Beth Boehm 


\section{ACKNOWLEDGEMENTS}

I would like to thank Dr. Russell Vandenbroucke for his patient guidance and passionate commitment to my work. He inspired me to do my best. Thanks also to Russ for helping me eschew prolixity. Thank you, Professor Tompkins, for being my mentor and sharing with me his love and knowledge of the theatre. I would also like to thank Dennis Krausnick for giving me the gift of confidence and the ability to open myself to others. And finally, thanks to my graduating classmates, Patti Heying and Robert Greene, without your support, your laughter and your dedication, I would never have finished this program. 


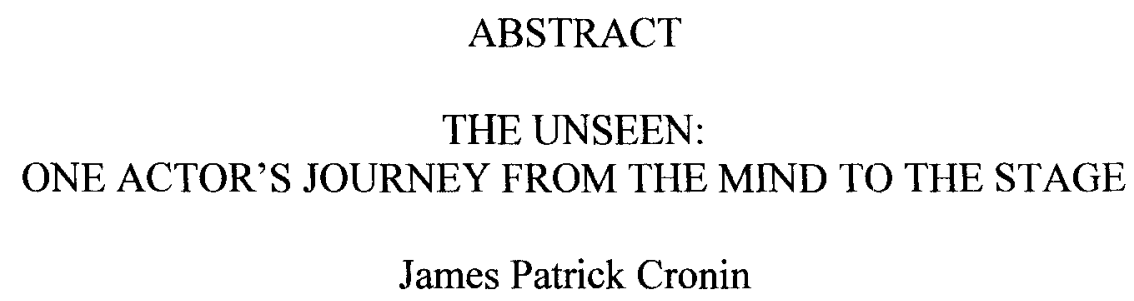

May 12, 2007

This thesis explores my work on the role of Charles Condomine in a production of Noel Coward's Blithe Spirit directed by James Tompkins. It is broken down into three main chapters covering the rehearsal process, character development, and performance. The rehearsal chapter compares the process of working with Tompkins on Blithe Spirit to the process of working with Dennis Krausnick on The Winter's Tale. I explore differences in directing style and discuss the advantages of each. In the character development chapter, I probe the personal choices I made in and out of rehearsals to bring Charles Condomine to life. The thesis culminates in a chapter that discusses and analyses Blithe Spirit performances, as well as some personal insights into why I prefer acting for the stage. 


\section{TABLE OF CONTENTS}

PAGE

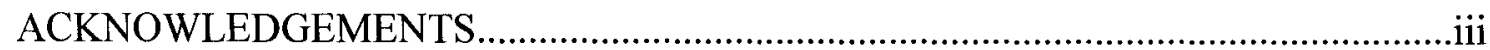

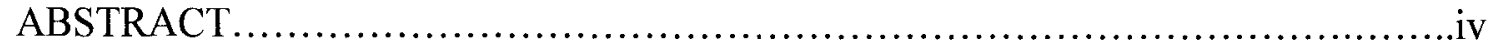

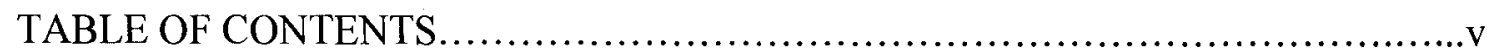

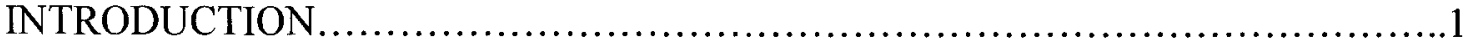

THE REHEARSAL PROCESS............................................................

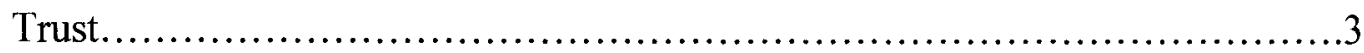

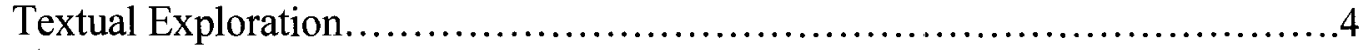

Pre-Rehearsal Meetings......................................................5

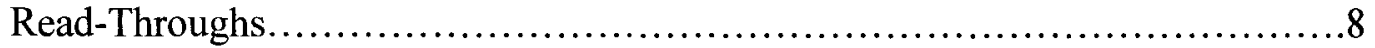

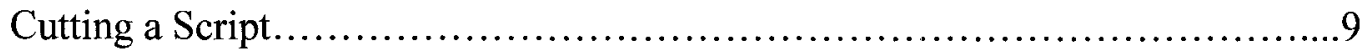

Early Rehearsals with Tompkins...........................................11

Dropping In with Dennis.....................................................13

Feeding the Play In .................................................... 16

Memorizing Lines.................................................... 16

The Middle Stages.................................................... 17

Run-Throughs.......................................................... 19

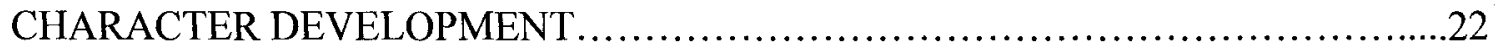

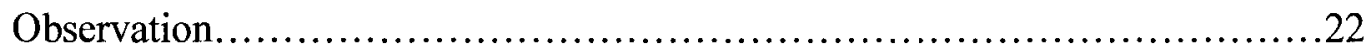

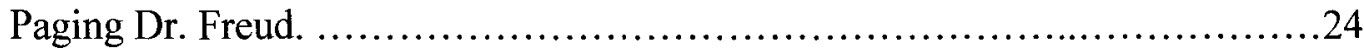

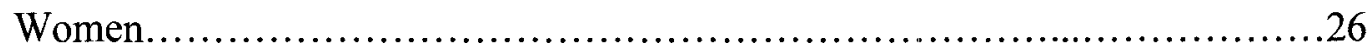

Find the Truth First........................................................

It's Not Who You Are, It's What You Wear..................................32 
A Rehearsal Costume................................................... 33

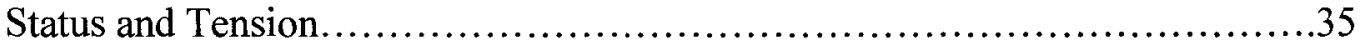

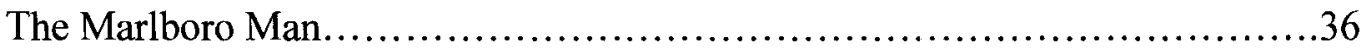

The Condomine Lean................................................... 37

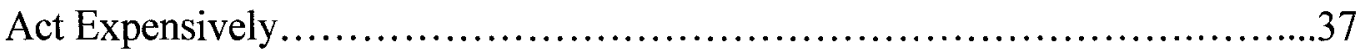

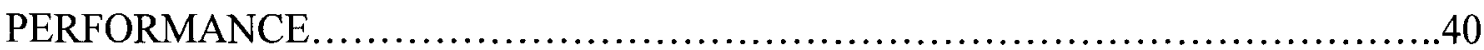

Ritual....................................................................40

Religion..........................................................40

The Power of Theatre Realized...........................................43

Connection Without Tears.............................................44

Opening Night Rituals..................................................45

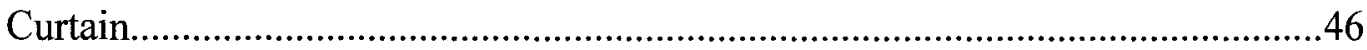

Opening Night Insights................................................. 51

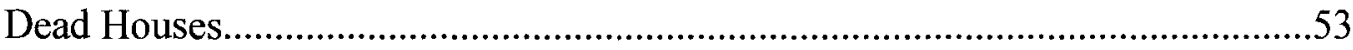

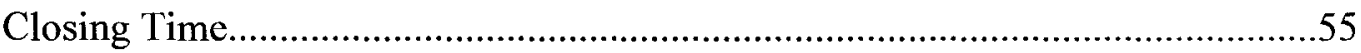

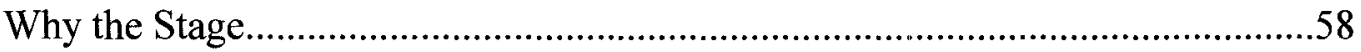

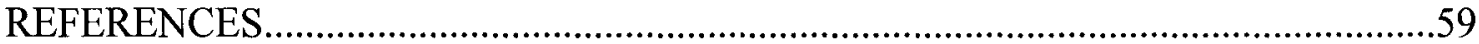

CURRICULUM VITAE.................................................................................60 


\section{INTRODUCTION}

In the opening scene of Blithe Spirit, Charles and Ruth toast the book that Charles plans to write about a homicidal clairvoyant. "To The Unseen," Charles says to his wife as they clink glasses (3). "I must say that's a wonderful title," Ruth retorts (3). And I must say, I quite agree. Since Charles never gets to write his novel, it seems fitting that I use his title for my thesis.

In addition, Charles and I both began with similar goals. Charles invites Madame Arcati to perform a séance so he might observe her and incorporate her mannerisms and personality into the lead character for his book. I undertook the role of Charles with a constant eye outside myself, observing my choices to codify my work in the theatre. Charles did his work with a martini in hand, I, holding a bourbon.

By maintaining a critical sense of my work and constantly working for greater self-awareness, I learned about my craft and began recording my approach. While Charles uses those people around him to motivate his writing, I turned my attention inside and used myself as a springboard for discussing the theatrical craft.

Though I focus heavily on the creation of Charles Condomine, I also include some analysis of the rehearsal techniques employed by Dennis Krausnick in a production of The Winter's Tale. A comparison of these directing styles is the substance of the first chapter. Chapters two and three cover character development and performance.

\footnotetext{
${ }^{1}$ This and all subsequent quotations from the playscript are from: Noel Coward, Blithe Spirit (Samuel French: New York, 1941, 1968). For future citations page numbers only will be noted at the end of the sentence.
} 
After Ruth compliments Charles's inventive title, Charles tells his wife "if this evening's a success, I will start on the first draft tomorrow" (3). Charles never did start that manuscript. Looks like I am one ahead of him. 


\section{CHAPTER I}

\section{THE REHEARSAL PROCESS}

In its broadest sense, rehearsal should prepare the actors for performance. But this definition does not give any substantive insights into the value and function of rehearsal. What are the qualities and skills that the actor should develop and hone during the rehearsal process?

\section{Trust}

Theatre is always collaborative. During the rehearsal process every player needs to make a concerted effort to bolster the sense of camaraderie, trust, and professionalism within the group. Like a sports team, an acting troupe must work together based on mutual trust and an unspoken connection that is supported and nurtured in the rehearsal hall and continued throughout the run. The onus falls on each individual to help foster such cohesiveness, but the director has a particularly heightened sense of responsibility for creating a healthy, positive work environment.

The value of this unity is multi-faceted. First of all, the rehearsal process is a period of exploration, often a period of minor and major failures. Actors must feel comfortable enough with one another to make bold, provocative character choices and not feel judged or threatened if a choice does not work or does not fit the mood or tone of a scene. This trust is also instrumental in creating unique, dynamic characters that play 
off one another in exciting ways. If an actor feels unsure of his scene partner, they cannot connect. If one person is too busy worrying about the other person's performance, that scene is doomed to be static and mechanical. Actors have to feel safe with one another so that their efforts will shine under the lights. Finally, trust allows the actors to explore the depths of the emotional content of a scene. In a production where the actors are not comfortable with each other, that distance could serve as a debilitating obstacle preventing them from reaching the emotional truth of a scene.

\section{Textual Exploration}

The emotional integrity of a scene leads to another vital element of the rehearsal process: exploring the text. Once unity is established, the cast and director can begin the exciting process of envisioning, revisioning, and sharpening the focus of a production. With the director at the helm, the ensemble steers the play toward production gathering insights into the theme of the play, the oscillating nature of the power dynamics between the characters, and the layers of emotional and physical action within the text. Notes from the director and discussions within the ensemble help clarify the company's vision of the play and help guide each actor stylistically toward revealing truths about the characters and the world of the play. This helps give the play a certain metaphysical, abstract shape. In other words, this part of the process provides a conceptual structure based on ideas.

Every director approaches a script differently. There are as many interpretations of a script as there are directors. Some experts refer to this as the director's concept. Others believe the director should find an image that symbolizes his vision for the 
production. Either way, the director is responsible for making sure his cast understands and believes in his vision and interpretation of the script. Each actor should be open to new ideas and willing to adapt his vision of the script to accord with the director's. In a quality production, all voices will be heard. The ensemble will bring all their ideas to the table and the director will mold them into a cohesive, workable vision.

But the production also needs formal structure, which is another function of the rehearsal process. This more tangible shape amounts to blocking the action and memorizing the lines. Though these steps can feel like tedious labor, they are essential to allowing the actor to achieve his full potential.

\section{Pre-Rehearsal Meetings}

Now that I have elucidated the general function of rehearsal, I will explore the application of these ideas in two different rehearsal processes. Although Professor Tompkins, who directed Blithe Spirit, and Dennis Krausnick, director of The Winter's Tale, seem diametrically opposed in their approach, I felt both processes helped me create a well thought out, strongly intentioned and emotionally committed character. I am intrigued that two approaches with two wholly different foci can both result in such positive experiences.

Neither director could cast the entire show from their first auditions. However, in both instances, I was cast extremely early giving me ample time to work on the play, specifically on my character development.

After Krausnick cast The Winter's Tale, but before he started the rehearsal process, he scheduled individual meetings with the principal actors. During this meeting, 
Krausnick and I talked about our impressions of the play. He shared his vision for the production, and we discussed some of the things I could focus on before we began the formal rehearsal process.

He pointed out that the role would be physically demanding and that he envisioned this character scantily-clad. For these reasons, he stressed the importance of eating right and exercising. These lifestyle principles apply to all actors and, admittedly are areas in which I need greater discipline. If the actor's instrument is his body and voice, then one of his daily responsibilities should be to keep his instrument in the best possible shape. A violinist does not throw her instrument around haphazardly. A basketball player does not spend halftime smoking Marlboro Reds. The performer should take equally good care of his instrument, his body and voice.

Ironically, actors seem frequently drawn to smoking. Bertolt Brecht suggests smoking in character as an acting exercise ${ }^{2}$, but most actors do not stop there. If an actor wants to perform at the top of his game, he must work to improve his vocal and physical strength, and there is no question that smoking inhibits this progress. I understand the appeal of smoking; I did it for seven years. It is a refreshing release from the emotionally charged work onstage. Though soothing and relaxing, smoking is also extremely detrimental to the instrument. Few talented professional athletes smoke. The physical demands of performance are similar for an actor; the process of taking care of the body should be too.

An actor in good physical shape will have the stamina to perform a compelling Shakespearean hero and the physique to pull off a romantic lead. Peak physical and

Bertolt Brecht, Brecht of Theatre: The Development of an Aesthetic. Trans. and Ed. by John Willett (New York: Hill and Wang, 1957) 129. 
mental health are fundamental to fully invested, committed performance. With weak tools, an actor can only build a weak performance.

In this early meeting Krausnick and I also addressed some of my preconceived notions about Leontes. In the words of David Auburn in his play Proof "crazy people don't think they're nuts." ${ }^{\text {,3 }}$ This is an important psychological point to remember in the theatre. I was having trouble detaching my personal feelings that Leontes was nothing more than a jaded, jealous tyrant. We looked closely at some of the early scenes and began to find ways to justify the actions and thoughts of Leontes.

Another hurdle that we had to overcome was that I had recently seen a poor production of the play and did not have much faith in the script. But Krausnick, by focusing on the mythic qualities of the story and the theme of the redemptive power of love, gave me a strong focus and clear direction that helped remove some of those reservations.

During Blithe Spirit Tompkins approached the earliest meetings differently. Because he had only cast three of the principal characters, we were limited in what we could do as an ensemble. Tompkins scheduled several meetings in his office in which we went over the French scenes that involved those three characters.

This felt choppy and prematurely specific. With the roles of Charles, Ruth and Madame Arcati cast, we could only work on a handful of scenes, which left me lacking any sense of continuity. However, one advantage to this approach was that Tompkins instilled an immediate sense of urgency and hunger. He got us working on the play early, which helped give us focus. This is also great practice for working on a film or television

${ }^{3}$ David Auburn, Proof (Gordonsville, Virginia: Faber and Faber, 2001). 
show in which scenes are not shot in chronological order and actors are expected to portray each moment with honesty and be able to do so on command.

\section{Read-Throughs}

Eventually both plays were fully cast and that could mean only one thing: the read-through. I cannot recall ever working on a play that did not begin the rehearsal process with a read-through, and to Professor Tompkins' credit, his read-throughs were never the same. In fact, Krausnick and Tompkins have given me three rather distinct approaches to the read-through each with their own advantages. For Doll's House Tompkins chose to have everyone read his or her foil's role. I read Torvald and Nora flip-flopped with Kristine. The effect was quite interesting. With everyone seated around a table, we dove into the text. Hearing my role voiced by someone else helped me analyze and internalize my part. I would hear certain line readings that did not sit well, others that I liked. It was much easier to be critical of that outside voice. Also, since I was not going to play Torvald, I gave everything I had to the reading, making bold choices, exploring as much vocal and emotional range as I could.

Switching the roles energized the group and got everyone much more actively engaged in what can otherwise be a rather stale evening. After the read-through, we all discussed different interpretations about several critical moments in the play and the candor of that discussion helped develop a healthy, creative work environment.

Krausnick also gave the read-through a sense of life and energy that I have rarely seen. The entire cast sat in a large circle and read the play. Those actors in a given scene would stand in the middle of circle and actively engage with one another. This 
effectively began the process of building character allegiances. It also got people on their feet, moving around and looking at one another. For the cast members that were not in a scene, the performance aspect of the read-through and the intimacy of the circle helped bring everyone into the action and hold their attention. We finished the read-through with a roundtable discussion about everyone's thoughts on the play and Krausnick's take on the overarching theme of the play and his concept for our production.

Our read-through of Blithe Spirit was the most traditional of the three. Once the show was fully cast, we met and read the script. There was no table, and the small cast formed a small circle. This read-through was the least exciting, but having already worked on some of the play, it felt good to hear the entire script and finally put faces to these other characters.

Of greatest value at this read-through was the realization of just how long the script was. Our reading lasted more than three hours, not including the ten-minute break for each intermission. By the end, we were all exhausted and, frankly, rather bored. Some serious cutting had to be done. We had already made minor trimmings to some of the scenes that we had been working, but we had much more to cover before this play was a reasonable length for a college audience, for any contemporary audience really.

\section{Cutting a Script}

Tompkins worked through the night making cuts. By the time we met the following evening, he had made significant trimmings to the first act. We spent the first hour and a half of rehearsal marking those cuts and arguing over the validity of certain passages, sentences, and words. This was one of the most frustrating parts of the process. 
Not only did I have a headache afterwards, but I also felt that valuable time working on the text was wasted. By the time we actually got on our feet, tempers were running high and energy was running low.

In contrast, Krausnick made substantial cuts to the script in advance, and a copy of the edited text was available before rehearsals began. Each actor was responsible for going through his own script and marking the cuts on his own time. No rehearsal time was wasted and we hit the ground running. Also, no one started memorizing lines that would later be cut. In fact, Krausnick was adamant about not memorizing lines before rehearsals began which will be discussed in more depth later in this chapter.

Admittedly, Tompkins was not fully aware of the length of the play and so he only had one night to make cuts which created several complications that bogged us down throughout rehearsals. Actors would frequently say lines that had been cut or wait for a cue line that had also been cut. Often this would throw off the timing or rhythm of a rehearsal, and in comedy especially, timing is everything. Also, actors who had already started memorizing were faced with the daunting task of unlearning lines. Ask any actor, there is nothing harder.

An aspiring playwright asked George S. Kaufman, who was known not only as a prolific playwright but also as a play doctor, for advice on his script. George, having never seen the text, replied "make it shorter."

Noel Coward and William Shakespeare wrote for audiences that had much longer attention spans and for whom the theatre was a great escape from their daily lives. Contemporary audiences demand bigger action in a shorter amount of time. How could we trim the script without taking away from the integrity of the story? Look for repeated 
information. Look for superfluous dialogue. Abandon the depth of focus on the minor characters and narrow the scope of the story.

The film version of Blithe Spirit is just over ninety minutes and Noel Coward was alive to see it produced. So I am confident that he would have been fine with the cuts we made. The integrity of the story remained intact, we just pushed it along a little faster.

\section{Early Rehearsals with Tompkins}

Professor Tompkins's directing style is meticulous and exacting, which is evident in much of his approach. We dove right into blocking. Early on, Tompkins made a lot of choices for the actors dictating when and where we should move, stopping and starting the scene frequently to move or reposition an actor. His first impulse seemed to be to create compelling and dynamic pictures. This directorial desire, like others, is coupled with the actor's responsibility of motivating every action on the stage. In Acting One Robert Cohen says that "every move onstage must be purposeful,", and working with Tompkins, this must become the actor's mantra.

Another aspect of Tompkins's specificity is vocal inflection. He is the first director ever to give me the note that a specific line must "go up at the end" or "go down." We endlessly discussed the importance of proper inflection and working with Tompkins has certainly heightened my sensitivity and awareness of the value and import of vocal inflection. "When in doubt, go up," Tompkins would remind us. "Take the line again. ... No, that's down. Try again. ... No, that's down again. Go... Better. Can you hear the difference?" At early rehearsals, he was patient, but as the rehearsal process

\footnotetext{
${ }^{4}$ Robert Cohen, Acting One $4^{\text {th }}$ edition. (McGraw Hill: Boston, 2002) 147.
} 
dragged on, he expected results faster and was not afraid to show his annoyance (justified in my opinion) at an inability to respond quickly.

Tompkins tells a story of Jerome Robbins doing the choreography for Moves at the New York City Ballet. One girl could not immediately imitate the steps to a routine, and Robbins showed no patience. "Get me another one, same size," he said. This story encapsulates the coldness of the business. It is a frank reminder just how good an actor has to be and just how quickly directors expect results. There are always hundreds of options for any role, so what can I do that separates me from the pack?

Tompkins brings out this dedication and professionalism in everyone who works with him. I worked hard in and out of rehearsals to be exacting and expansive with my vocal choices. I also spent a lot of time honing the cooperation between my ear and voice so that I could change a line reading instantly.

Early rehearsals were taxing and frustrating for everyone. During breaks, many of the actors would discuss difficulties, like the feeling that we lacked a sense of flow. Tompkins would stop us so frequently that sometimes it would take thirty minutes to get through two pages of dialogue. I would often forget what the scene I was working on was about or even why I was talking to the other character because Tompkins had me try so many different interpretations of a line or beat. For a good portion of the early rehearsals, confidence in the cast was rather low.

One note that we got very accustomed to was "that was yesterday." We would perform a section the way we were directed the previous evening and Tompkins would stop us. "But that's what you told me to do," we would say sheepishly. "That was 
yesterday," Tompkins would retort and then proceed to try something new. I am glad I did not write any of my blocking notes in my script (talk about a lesson in futility).

Though it failed to give me the structure I am accustomed to, the process did provide me with an open and flexible mind with regard to my choices. I began looking for novel approaches to a line reading or a fresh justification for a cross. Oftentimes, I would do something differently and Tompkins would allow me to continue, not because he was not paying attention, but because the action made sense. It became clear that what he was actually concerned with was the flow of the material and our justification of the moments. He stopped us every time he did not believe us. Every time we were "acting!"

\section{Dropping In with Dennis}

In stark contrast to this technical, methodical approach was Krausnick's "dropping-in" method. Our first rehearsal was a brief explanation of the process and then we began. During our first week or two of rehearsals, we dropped in the entire play. The cast gathered in a circle around three chairs. Krausnick sat in one, I sat in another, and Luke Holladay, who was playing Polixenes, sat in the third. Holladay and I were instructed to relax, sit up straight, breathe deeply, and focus on each other. We sat directly opposite one another with Krausnick at our side. Our hands resting gently at our sides, our eyes in direct contact and our legs intertwined, Holladay and I listened as Krausnick began whispering words and phrases from the script in our ears. Whenever he said a word from one of my lines, I would repeat the word, sending the energy and tone of the word to Luke. Then with each word or phrase, Krausnick would ask questions. These questions ranged from the intensely personal to the absurdly comical, but mostly 
required a serious exploration of relationships and feelings that existed for both the actor and the character. There was a certain ambiguity to the questions that blurred the line between me and Leontes and my relationship to Holladay and Polixines.

This method was the reason that Krausnick did not want us to memorize our lines beforehand. He wanted us to come in pure, to hear the words for the first time, not including the read-through, and to avoid getting ahead of ourselves. If we did not know what word came next, we could respond more openly and honestly to its various connotations. We continued this way for about an hour. Our eyes got watery. Our muscles got stiff. We had only worked through about a page and a half of text. After Krausnick had dropped in the scene, he went back and fed us sections at a time. We repeated our lines to our partner. He then asked us to relax, collapse our spines and stretch and breathe.

Once the cast was familiar with the process, we broke into smaller groups with some of the graduate students helping to drop in the smaller scenes. Krausnick always worked on the scenes that I was in, almost always as the person feeding me lines and images. The timber of his voice had a soothing, lulling quality that evoked incredibly visceral responses. He always asked provocative questions and knew just how to phrase them and in what order to ask them to achieve the greatest emotional response.

As a cast we helped each other endure the physically and emotionally draining process of dropping in an entire Shakespearean play. During scenes we worked in groups. I had several soliloquies during which Krausnick had me face the entire cast. This process, though extremely challenging, was also very rewarding. Working these monologues, Krausnick asked me a litany of profoundly personal questions that 
addressed my sex life and the emotional scarring of several deaths in my life. Though I did not have to answer the questions out loud, the simple act of thinking about those pains sent me to very dark places. At times I felt suffocated and claustrophobic; for the duration of the dropping in, I felt totally exposed and impotent.

In spite of these difficulties, I reached a new level of freedom in my acting. My ability to keep eye contact while my mind was exploring these dark ideas was a huge step toward greater emotional availability and trust for those around me. Also, the personal nature of the questions created a much deeper sense of connection to the character. I began to understand Leontes and saw the possibility in my own life for some of the harsh, rash decision-making that drives this troubled king.

Richard Dreyfuss has said that, "What actors can do without lecturing is show that in each of us there is Hitler and Jesus, and if you are a truly gifted actor you can find that in you, and bring it out, and say, 'See, we share this." "'5 By dropping in the script, Krausnick helped me find and acknowledge these contrasting parts of my own personality and consequently made it easier to find those traits in Leontes.

However, this discovery had a price. Although this process helped establish an intimate bond among the cast and solidified a strong, personal connection to the character, I did not possess all the emotional control that I wanted, both for my personal sanity and for my ability to play and replay moments in rehearsals. Several times during rehearsals, images and memories of painful times in my life came flooding back to me uncontrollably. Once these memories came, I did not have the power to remove them at will. Often, I took mine and Leontes's demons home with me and had a difficult time

\footnotetext{
${ }^{5}$ Robert Cohen, Acting One, 99.
} 
overcoming some of those dark moments. Although I liked feeling such a strong bond to the character, I wished I could leave it in the rehearsal space.

\section{Feeding the Play In}

Following the completion of the dropping-in method, we moved to "feeding the play in". This consisted of getting the play on its feet without scripts in our hands. An actor without lines in a scene would stand behind another actor and give him phrases of dialogue. That actor would say his line to his scene partner and then listen for another chunk of text. It took two days to complete the play utilizing this method.

The most obvious benefit was that we did not have to worry about the script, but instead could focus all our energy on our scene partner. It got us exploring our physical presence and our physical relationship to the other characters.

\section{Memorizing Lines}

Both of Krausnick's early methods helped tremendously in memorizing the part. The lines already felt a part of me and everything Leontes said made sense. I never needed a script in my hand for the entire rehearsal process: how liberating!

This was not true, however, for Blithe Spirit. Because lines continued to be cut, added back and manipulated throughout rehearsals, it was very difficult to remember them. Also, memorizing through blocking has always been an effective memorization method for me, and since that kept changing, I did not have any mental images or repeated actions to help me recall my lines. 
Memorization is a banal, yet extremely important part of the acting process. If acting is about connecting to other people, then not much acting can go on when there are scripts in hand. It is not natural. In life, people do not go around with words to say written on sheets of paper. Furthermore, with the text in hand, the actor's focus is split between his scene partner and the lines on the page.

Memorize as quickly as possible. An actor has to know his lines so well that they simply become part of him. If an actor is thinking about what his next line is, he is out of the moment. The thought process must be focused on the other actor and how they are affecting new responses. If the thought is, "what's my cue," "What do I say next," or "what's my next line," the moment lacks authenticity.

\section{The Middle Stages}

During the middle stages of rehearsal similarities between the two directors began to emerge. Both Tompkins and Krausnick preferred working on the play in order, so that was how rehearsal was structured up to the run-throughs. With Tompkins in particular, I distinctly remember how thrilled the whole cast was when we got through the entire first act without stopping. Like Georges Seurat, we finally got to step back from hours of meticulous pointillist work to find that we had in fact created a discernable portrait of a Noel Coward play. Tompkins still gave detailed notes about painfully specific moments, but now he was waiting until the end of an act to deliver them.

Structurally, this is also how Krausnick worked, but his notes tended to move in an entirely different direction. Krausnick was concerned less with blocking and inflection and more with thoughts and emotional exploration. We would finish a scene, 
discuss it extensively, and then repeat the scene with these freshly discussed ideas in mind. One scene in particular, Act II scene i, Krausnick gave me the note: “don't stop moving the entire time. Hit the wall with your fists. Throw things. Yell." We performed the scene four times, each time I got more and more frantic and physical. By the end of the fourth run, I was exhausted. Krausnick told me privately that I would eventually have to remove all that superfluous movement, but that I should never give up the intensity and rage that movement and violence helped me achieve.

Both directors held rehearsals four hours a night, but used the time in slightly different ways. Krausnick began every night with an extensive Linklater warm-up, taking up to forty-five minutes to loosen everyone up and open up our voices. He would also incorporate several breaks into the evening. Tompkins, on the other hand, was more like a slave driver. We would begin promptly at seven o'clock and worked scenes extensively until around nine-thirty. This was usually when someone pointed out that he/she had to go to the bathroom. We would break for ten to fifteen minutes and then work hard again until eleven, sometimes even later. Both rehearsals were tiring and rewarding. For the most part I enjoyed being at both, and did not mind the long hours or intensive training.

Both Tompkins and Krausnick know how to fill the time. With the exception of the line-cutting rehearsals for Blithe Spirit, I never felt time was wasted. Additionally, both directors pushed me to new heights. They challenged me to do my best and refused to settle for anything less. They shared an argosy of fresh insights that always kept me on my toes, learning. My goal is to create the most complete, honest, captivating character that I can. That simply requires a strong focus and demanding time commitment. 


\section{Run-Throughs}

Run-throughs test the arch of the piece. What is this character's journey? Is the goal clear and playable? Does the struggle have a beginning, middle and end? When working through the entire play, the answers to these questions should become apparent. And if it is not clear to the performer, then it will definitely not be clear to the audience.

Props can also change the rhythm and intensity of a moment and must be practiced rigorously to achieve the best results. My character smoked several cigarettes onstage and that adds a timing element. There is nothing I hate more than watching an actor light a cigarette, take one drag and then put it out. Real people do not do that. It is the actor's responsibility to find time to smoke most of the cigarette. Otherwise, do not bother lighting up. I also mixed drinks, which takes time and cannot be faked. Once the props are brought in, I can practice making martinis in an expeditious manner so that Madame Arcati has her drink as she is supposed to say, "thanks. Cheers!" (10).

Run-throughs that take place on the stage also have an added boost of energy as compared to working in a rehearsal room. Both Tompkins and Krausnick rehearsed onstage as frequently as possible. Sightlines change. Distances change. A cross that took three steps in the rehearsal room takes six steps onstage. Acoustics change. All these factors need to be processed, analyzed and adjusted for the stage.

During one of these final run-throughs, Tompkins said something that took the play to a new level. He told us: "I have done all that I can. I have worked you and worked you and now it is time for you to make this your own. I have given you a foundation that will prevent you from falling, but you must be bold enough to stand up 
and make this play shine. Take ownership over the work you've put into this and have fun with it. And if it's a miserable failure, I already have my plane ticket to Brazil." After all the discipline, all the notes, all the starting, stopping and reworking, Tompkins turned the onus of responsibility to us and, having so well prepared us, we were glad to take it. Tompkins made me feel confident in my work and my choices and this note gave me greater courage to explore even stronger choices, to find even more joyous moments onstage.

But Tompkins's confidence building did not stop there. He also encouraged us to have fun with the train. During performances in the Thrust Theatre, there is a train track that runs directly behind the building and its whistle blows at an extremely audible level. It frequently happens at inopportune moments during a production and can kill dramatic tension. Tompkins told us that if it could be justified, we could make an improvised comment about the train and then return to the scripted dialogue. Our production was in such tight shape that we could afford to start to play with it again. And play with it we did.

Tompkins's concern is for the scenic truth of a moment. He wants to see his actors playing well-established intentions and focusing on playable, interesting actions. Krausnick's concern seems more about emotional commitment and the mythic storytelling qualities of a theatrical piece. As Tompkins would say, he is concerned with drama, whereas Krausnick is concerned with theatre. While I can certainly recognize the differences, and felt them in my performances, I enjoyed both experiences and have a tough time determining whether or not one method has any more validity than the other. These are simply two different approaches resulting in two different products. 
But the discussion in this chapter only begins to touch on the hours of probing work that goes into making a strong, interesting character, the subject of the next chapter. 


\section{CHAPTER II \\ CHARACTER DEVELOPMENT}

Character development is a continual process that takes place in and out of the rehearsal room. Character development requires several different skills, including some that can be worked on daily. I have already discussed the importance of being in peak physical condition which factors into an actor's daily life. Every choice about diet and lifestyle influences the actor's instrument. A committed actor should be aware that choices made throughout the day affect his craft. So how can an actor make smart daily choices that improve his instrument?

\section{Observation}

One of the actor's most valued assets is his power of observation. This tool functions in a variety of capacities, and once honed it should become a vital part of the actor's daily process. The actor's power of observation works in two directions. First, the actor works to achieve a heightened sense of awareness of the world around him. Even when not working on a specific character, a good actor observes those around him, cataloging different human tendencies for later projects. Like a child whose eyes are new to so much of the world, the actor should engage in active people watching making observations like these: How does that person walk? Listen to the subtle lisp that person has when he speaks. Look at the way she is eating that sandwich! 
I find myself constantly staring at others, watching their movements and then mimicking them. Whenever I am in a conversation with someone who has a foreign accent, I catch myself slipping into that person's speech patterns. Though some people may find this mimicry rude and condescending, these habits help develop an honest and specific set of physical and vocal choices that I can bring to the fore with any character that I am working on.

The second focus of observation is internal, requiring the actor to turn the mirror on himself and look honestly at the reflection. A strong actor must be aware of his own tendencies. For example, I like to twirl my hair. To avoid doing that with every character onstage, I first had to realize that I had the habit. Some natural tendencies are much subtler and require deep personal reflection to pinpoint and control. Complete awareness of all habits and mastery over the self takes a lifetime. Tendencies shift and the actor must constantly be aware of new personal ticks and work diligently to control them.

Below this superficial layer of observation lies an emotional component. Effective emotional observation is geared toward analyzing, codifying, and storing responses to different stimuli. No actor is ever wholly involved in a moment. There is always a part of the brain observing the response and recording the results. I am in pain, the person thinks. Meanwhile, another part of the brain is asking, where does that pain live? Where is the physical tension? When I am crying, what does that feel like? Emotionally? Physically? This analysis takes place with an eye toward being able to recreate a given response honestly and naturally. Many actors wonder if they ever feel a genuine emotion because they are constantly observing their own feelings. Though 
somewhat cold and calculating, this is a part of the craft, something to embrace by anyone who takes acting seriously. Without knowing what my personal tendencies are, how can I effectively manipulate and shape them according to the demands of a specific role? The actor must first know how he acts and how the world perceives him, before he can begin the journey to quality character creation.

\section{Paging Dr. Freud}

Perhaps because I grew up in a household with parents who were constantly psychoanalyzing my thoughts and actions, I begin the exploration of every character with his psychology. How does this person think? What are his likes, his dislikes? When does he get up in the morning? How does he take his coffee? Is he good with children? These are just a few of the questions that help me dive into the mind of any fictional person.

Also, we are products of our environments. Charles's methodology is invariably going to be informed by his culture and era. To that end, I seek out literature and art from the period to get in the proper mindset. For example, during The Winter's Tale, I read E.M.W. Tillyard's The Elizabethan World Picture. Although the character is Sicilian, familiarizing myself with the playwright's world allows me to make choices that accord with the Elizabethan prism that the text shines through. With this foundation, I could then paint a specific portrait of Leontes, the jealous king.

Different societies have different views on the role of women, politics, religion, education, and so on. And in order to give an honest portrayal of a man from any given time period and culture, I start familiarizing myself with the prevailing theories of the 
time. For example, when Charles says "Women, my God what I think of women," a contemporary, feminist audience could construe the line as sexist and offensive, but for Charles the sentiment is a natural reflection of his own perceived superiority (35).

To better understand the prevailing methodologies of the period, I took a virtual (online) tour of the Tate Gallery and the National Portrait Gallery in London. I read other popular British works of the period like Arthur Conan Doyle's Sherlock Holmes series. I listened to popular music of the time, including some standards by the playwright himself. Having read a great deal about the Algonquin Round Table, I was also familiar with the prevailing sense of wit and humor of the period. Though there are certainly differences between British and American humor, a greater understanding of the wit, language use, and style of humor from the period, whether British or American, would still help inform the approach to the role. While it is important to be aware of the possible differences in taste, much of the language, rhythm and references will ring true from either side of the pond.

This historical research helps clarify how a character fits into the world of the play. Once I have a sense of the character's worldview, then I can determine his place in society. How do other people view him? How does he view himself? What kind of status and power does his occupation hold? What about the neighborhood he lives in, the car he drives, and so forth?

Part of my research for this role entailed watching the film version of the play starring Rex Harrison ${ }^{6}$. It helped remind me of the formality of the period and gave me a stronger sense of historical reference. Seeing the world of the Condomines filled some of

${ }^{6}$ Blithe Spirit. by Noel Coward. Directed by David Lean. United Artists. 1945. 
the holes that my imagination had left blank while envisioning the play. Some people do not like watching someone else perform a role that they are working on. They are afraid that their own performance will inevitably mimic the production they watch, so they avoid the film. I think it can be extremely beneficial. Harrison made some choices that made no sense. He missed the humor in the role and spent way too much time being slick. However, there were moments that were fantastic. He had a sense of the style that I had not yet reached. I absorbed what I felt worked and learned from what I perceived as some of his weaker choices. Watching the film version just gives me more weapons in my arsenal, more options onstage.

Once I felt accustomed to the period and comfortable with the thought process of the character, it was time to flesh out the content of my character's relationships.

\section{Women}

Charles's female relationships best illuminate his world. There are four women that help shape his stage presence. It is my job to find the truth in all these relationships and bring them to life. But like any relationship, feelings change over time. With one relationship in particular, Charles's feelings changed dramatically during the rehearsal process.

Naturally, relationships morph and develop. Hopefully they are growing and becoming clearer and more interesting as the rehearsal process moves along. This was certainly the case with me and Frances Lewis, who played the maid Edith.

Early in the rehearsal process, I felt Charles really enjoyed Edith. She was spunky and high energy and I think Charles responds to that. As we got deeper into 
rehearsals, I found that idea changing. I began thinking about the fact that she is on the payroll and that I have certain expectations from my staff. Edith, though free-spirited, was not learning the ropes fast enough and that bothered Charles.

Charles looks to take advantage of almost every relationship. This is true of his relationship to Edith as well as with Madame Arcati. Charles views her as nothing more than a science experiment. But how does this mentality influence and shape the character choices I made with regard to Madame Arcati, played by Patti Heying? Whenever Madame Arcati was onstage I found my focus drawn intensely to her. As a writer, my character watched her every move searching for insights into her psyche. I watched her eyes, her hands, her neck: anything and everything that would give me a peek into the mindset of a clairvoyant.

Charles sees Madame Arcati as research material, but always remembers his sense of social status. He treats Madame Arcati with a feigned sense of respect that helps establish a social setting comfortable enough for her to be herself. As the play goes on and Charles loses his grip, his ability to behave with appropriate social restraint around Madame Arcati also crumbles. He becomes more and more informal with the woman who introduces so much chaos and confusion into his life.

The source of this chaos lies in Charles's vastly different relationships with his two wives and the force of their opposing pressure on his will. Charles loves both his wives, but he clearly loves them for different reasons.

Charles and Ruth seem to get along in a genial way. Their relationship is predicated on intellect, respect, and convenience. Charles feels comfortable with Ruth. She knows how to run the house, she helps him with his writing, and she has a pleasant 
sense of humor. Charles is attached to her maternal qualities and her maturity. This is illustrated in his conversation with Ruth at the beginning of the second act when he tells her, "I've always looked upon you as a woman of perception and understanding" (32). Though people's feelings cannot be judged solely on what they say, this comment accords with the nature of this marital relationship.

In contrast, Charles's relationship with Elvira is based on more primal instincts. Their relationship is founded on having fun and socializing. Charles accuses Elvira of concerning herself with nothing more than superficial pursuits in the third act: "All you ever thought of was going to parties and enjoying yourself" (68). While I do not imagine that Charles and Ruth sleep together often, I imagine that Elvira and Charles had an active sex life. Their relationship revolved around going to events, being social and keeping each other jealous by exploiting their sexual prowess. They discuss several affairs that they had during their marriage and seem to use sex as a weapon.

Charles and Ruth may not have the most fun relationship, but it certainly seems stable. Charles and Elvira did not have the most stable relationship, but it was definitely a lot of fun.

Late in the rehearsal process, Rhea Lehman sat in on a run-through. After the first act, she told me that I had to clarify my relationships with my two wives. And then she guided me to an invaluable insight into my character, and one that I will use with many future roles. In terms of my relationships with these women, I was dwelling on the negative. Ruth was no fun. Elvira was immature. And while this wasn't necessarily false, this attitude was not allowing me to pursue anything or have any fun onstage. 
"This play is a power struggle," Lehman pointed out. "It's a fight between these two women for your affection. Enjoy that more."7 I could feel a weight lifted. Instead of feeling bogged down by the woman who was stifling me, all I had to do was focus on the fun I was having with the other one. Do not think about Ruth's inability to play, dwell on her peaceful sensibility. Do not obsess over Elvira's immaturity, but rather enjoy her charm and grace. Once I thought about the women in this way, I began having fun onstage. Instead of feeling pulled against my will, I decided to gravitate toward the more enjoyable relationship.

Charles loves both women, but that can be hard to illustrate simultaneously. I cannot play gray. Gray reads as ambivalence or as a weak choice. But what I can do is play black and white in constant, sometimes frenzied succession. Instead of trying to love both women always, Charles could jump back and forth between overwhelmingly positive emotions for both of them.

The struggle begins the second Elvira materializes onstage. Though Charles is drawn by Elvira's overwhelming sensuality, he also remembers his allegiance to Ruth. "Get rid of her Charles, and then we can talk in peace," Elvira suggests just moments after her arrival (28). But Charles's heart is still with Ruth. "That's a thoroughly immoral suggestion," Charles retorts, "you ought to be ashamed of yourself" (28). However, just a few moments later, after Ruth has rushed off to bed, Charles is reminded of the things he loves about Elvira. He confesses that "[he is] delighted in one way" (29). Charles remembers the silly conversations they used to have, the passionate kisses they shared, and his allegiance for Ruth disappears instantly. Lehman helped me think

\footnotetext{
${ }^{7}$ Rhea Lehman, "Blithe Spirit Rehearsal." University of Louisvillle. 19 Sept. 2006.
} 
positively about the two relationships and helped polarize them, which makes the work more fun, easier to pull off and clearer to an audience.

Part of this discovery is the fundamental knowledge that I should always play the positive. Rinda Frye would remind me in voice class that I cannot simply quit smoking. Instead, I have to start doing something else that fills that void. I cannot just not smoke, but I can think more positively about my health and make more constructive decisions regarding my wellness. The one is positive and active; the other is negative and latent.

\section{Find the Truth First}

Once I have a sense of the character's mental development and makeup, I use those insights to build a unique physical presence onstage appropriate for the character. Obviously, one of the elements of Blithe Spirit that I had to tackle was the fact that Charles is British. I have worked in classes and on several projects that required a British dialect, but nothing on such a major scale. I wanted to begin working on the accent immediately, but Tompkins put a stop to that. During our first few reads of the text, he insisted that we maintain our normal speech patterns and accent. "Putting an accent on these characters now would just be adding a layer of artifice," Tompkins continued with cool sagacity: "First you have to find the truth of these moments. Know what you're saying and why you're saying it. Then you can add an accent."

For a while it was hard. I had read the play with an accent in mind. I heard Charles's staid British tongue, but I fought against these urges and focused on the truth of each moment. It took several weeks of this work with standard speech before I started exploring dialect. Once the dialect work began, it was incorporated gradually. If 
Tompkins felt that we were getting too far from the truth of the scene, he insisted that we drop the accents and work the material naturally until we keyed back into the honesty of the moment.

During one of the middle rehearsals, Tompkins made another great point: "If you're playing the truth of the moments, if you're making strong connections onstage and really working together, the audience won't care if the accent is a little shaky. If the performance is compelling, if the choices are bold, the audience will forgive you." $\mathrm{He}$ nailed it again. I thought about several roles that I had seen performed in which a strong performance was coupled with a weak accent. That never bothered me. This is not to say that I am unaware of the poor dialect work, it simply implies that the accent is secondary to creating truthful stage moments. Certainly when I am watching an inauthentic performance, then I am quick to criticize shoddy dialect work.

The effort to create the most authentic representation of this upper class British dialect is still required. I had been trained to take deep breaths and let the sound out with the air in my lungs. But Tompkins told me that this was weakening my speech. I sounded pathetic and self-pitying, he said. "Clip the sound, James. Get the air out of your voice," he would repeat constantly: "Again James, too much air. Hold your breath and get the sound to the front of the mouth."

The soft, airy vocal quality that I had begun the rehearsals with was inappropriate for Charles. Charles is quick, sharp, and edgy, not soft, round, and smooth. The voice has to match the quality of the character. That meant emphasizing the consonants and plowing through the vowels. My natural tendency with a British accent is to add weight 
and a certain musicality to the vowels. For Charles, I needed to abandon that habit and articulate my consonants.

The biggest hurdle in this process was splitting my focus. I had not only to stay in the moment with my scene partner, but also to hear myself talk and listen for the air in my voice. For a while, the focus was primarily on my breathing and my speech patterns. The air was coming in less and less frequently until eventually I felt confident enough in the vocal work to focus exclusively on my scene partner.

I used visual images to help conquer this vocal obstacle. It helped to think of the words being formed on the tip of my lips, rather than in my throat or in my belly. The further out I could make the sound, the sharper and crisper the delivery. I imagined the words were knives shooting out of my mouth and cutting those people who got in the way. This, coupled with Tompkins intense inflection work discussed in the first chapter, brought specificity and life to the voice of Charles Condomine.

\section{It's Not Who You Are, It's What You Wear}

My father owns a sweatshirt that says "Chill Out Man. It's not who you are, it's what you wear. I mean, who really cares who you are anyway?" While this sentiment smacks of the superficiality of the Los Angeles culture that produced it, the idea still resonates with a certain truth that it useful on the stage.

Clothing does speak volumes. The costumes that people choose in their daily lives visually indicate a great deal of their social preferences. People wear styles that they like, that flatter them, and those choices compartmentalize them into various cultural niches. Not only the styles, but also the labels themselves associate people with 
particular groups. People that wear the hip-hop labels like Sean John and FUBU hang out with others wearing G-Unit gear and RocaWear. People in Ralph Lauren and Tommy Hilfiger are just as inclined to fraternize with similarly dressed individuals.

The formality of a chosen outfit also commands a specific kind of respect and indicates how seriously someone takes a specific event. When I teach a class, I do not wear sweatpants. The quality and content of the information that I disseminate does not change, but the student's respect and interest in what I am saying is partially contingent on my appearance. A dress shirt and slacks demands more respect than a t-shirt and jeans. That is a fact.

\section{A Rehearsal Costume}

How does this relate to the stage and my process? Like most actors, I do not choose my character's clothing, the costume designer does. This is a byproduct of the collaborative nature of theatre, and does not have to be viewed as limiting an actor's individual choices. Costume pieces always inform my work in deeper and richer ways. Michael Chekhov writes in On the Technique of Acting: "'I took the first piece of clothing I came across, put it on and felt who I am. ",8 I work in a similar fashion. Costume fittings are a vital part of my character development. I like to know early what my character is wearing and, if possible, begin to wear some of the clothing immediately. These clothes belong to the character. He went shopping for them. He picked them out. He has worn them before. He has his favorite outfit, his most comfortable pants, and his softest shirt. This level of familiarity and comfort can be very difficult to fake, so it is

\footnotetext{
${ }^{8}$ Mel Gordon, Introduction to On the Technique of Acting by Michael Chekhov (New York: Harper Collins,1991) x.
} 
extremely important to live in those clothes as long as possible to foster a personal connection to the outfit.

However, actors often do not have the luxury of being able to wear their costume pieces early in the rehearsal process, as was the case with Blithe Spirit. In fact, I did not try on some of my costume pieces until tech week. Even in this situation, it is still possible to begin the process that allows the clothing to inform the work. I had seen the costume renderings. I knew what the designer had in mind. Charles wore suits, or at the very least dress slacks and shoes. With these images in mind, I pulled something appropriate from my own closet to begin exploring how the clothing affects this character.

Every night before rehearsal, I changed into a brown, double-breasted wool suit, dress shirt, tie and loafers. The transformation was almost instantaneous. I walk differently in loafers. The clip-clop of the hard-soled soles on the wooden floor brings a smooth rhythm to my gait. The line of the pants and cut of the jacket lengthen my spine and improve my posture. I can feel my chest swell up. The clothing adds status and is linked symbiotically to the physical life of the character. Only by rehearsing nightly in a similar outfit did I adequately prepare myself for that first rehearsal in costume.

Once I have explored how the clothing changes my physical neutrality, I must then determine how Charles's body in a suit differs from my body in a suit. How does his socio-economic standing and general worldview alter the way that he stands, sits and lives in his costume? 


\section{Status and Tension}

I use the character's costume to inform and specify the character's physical life, but I have found that physicality is something that I approach later in the rehearsal process. I need a sense of the blocking and a familiarity with the lines before I can begin to explore the physical presence of my character. Once I am clear on the character's objectives and his status in society, then I can find his stature.

Charles is high society. He has money and a high degree of respect within the community. He likes good gin and classical music. He spends his leisure time reading. He smokes expensive cigarettes. Charles is a high status individual and immediately this translated onstage into a certain stiffness.

Tompkins suggested that I take larger steps with Charles, that he covers more ground when he moves. I did this, but my knees were locked. The steps looked clumsy and awkward. My back was straight and my posture was good, but everything was tense. I could feel the energy locking through my shoulders, tensing throughout my spine. This was my physical sense of high status, until Tompkins gave me one of the best notes I have ever received. "High status," he said, "does not mean tension. In fact, it means just the opposite. Tension is for people who do not know where their next meal is coming from. Charles does not want for much of anything. He runs the show. He's relaxed and very comfortable in his world and in his skin." Just because he is high class, does not mean he has to be stiff. Rigidity reads as uncomfortable and Charles is exceedingly comfortable in his surroundings.

Once I internalized this note, Charles began floating around the stage. I sat with ease, crossed my legs effortlessly, and stirred my drink calmly. Beginning the show with 
this level of comfort allowed Charles to go through a clear, clean physical transformation once the ghost of his first wife appears. Elvira's arrival rattles Charles's nerves and his sense of control is pressed incessantly for the next two acts. This creates palpable tension. How does a man who is so concerned with appearance and image respond to stimuli that uproot his sense of calm and sophistication?

\section{The Marlboro Man}

An ever-growing sense of unrest caused several changes in my physical presence. The first of these is the way Charles smokes his cigarettes. Perhaps one of the few benefits of having smoked for years is that I can do it effectively onstage. A non-smoker holding a cigarette can be quite distracting. It looks like a foreign appendage when it should be a natural extension of the arm. Early in the play, I chose to smoke with slow, easy drags. I held the cigarette between my index and middle fingers and tapped the ash off with my index finger, rather than flicking the cigarette against the ashtray. But as Charles began to unravel, the choice to smoke was motivated more by a desire to calm down rather than to enjoy a moment or to look good. The smoking became more frantic. The drags were shorter and I tapped the ash off the cigarette more or less frequently depending on just how distracted I was. Another key shift in Charles's physical life was the tempo. As ghosts materialized and Charles thought he was losing his mind, I chose to increase his speed. Movements became both more numerous and more rapid. Charles was doing more and he was doing it faster. With an increase in nervous energy, I felt compelled to move more frantically through the space. 


\section{The Condomine Lean}

These are some of the bigger choices that I made physically for Charles, but there was an additional, subtler choice that I have coined the Condomine Lean. When I was exploring options for Charles's physical center, he struck me as an intellectual, heady person, but he also seemed very grounded and sure of himself. Part of me wanted to lead from my head, while another part felt compelled to move from the stomach or pelvis. When still, these conflicting energies shifted my weight to one side. I found myself standing with all the weight on my right leg, which instantly felt appropriate. I continued to play with this sense of balance. The slight shift in center, the feeling of being just offbalance fit perfectly with Charles's personality.

Charles is relatively unstable. He is quick to criticize and quick to act. The off balance stance charged me with an odd sense of calm. I looked comfortable, but there was something about the position that kept me poised and ready for movement. The positioning also reminded me that Charles was easily shaken.

\section{Act Expensively}

During the rehearsal process, Tompkins always stresses the following mantra: “Act Expensively!" While I am working on developing my character, I try to remind myself of this creed. This is a brilliant sentiment that, if practiced, carries a performance to the outermost reaches of believability. That is where great performances lie. Push the limits. Extend myself to the very edge. Acting expensively is about making bold, courageous choices that create a unique and dynamic character that remains truthful and realistic. 
Krausnick once advised me, "chance doing the opposite." Whatever my mind tells me, just try the exact opposite. Sometimes it does not work, but sometimes I find an exciting new way to deliver a line, make a cross or interact with another person onstage.

John Stuart Mill wrote that there is no such thing as a bad debate because if you stifle a free exchange of ideas and "the opinion is right, they are deprived of the opportunity of exchanging error for truth: if wrong, they lose, what is almost as great a benefit, the clearer perception and livelier impression of truth, produced by its collision with error." Acting expensively and trying the opposite both reinforce this idea. Some choices may not work, but others may take the character to a new level of truth. The rehearsal process is the time to test the waters.

Make big, expressive choices. Try things physically and vocally that push the edge of reality. The best performances are the ones that find that edge and dance on it all night long without ever going over. Rehearsals are a great place to overshoot the mark because it is easier to pull back a little than to creep closer to the precipice. A moment in Blithe Spirit that comes to mind is the scene at the end of the first act after Ruth storms off to bed. Elvira tells Charles, "I loved you very much" (30). I walked upstage to the stairwell to make sure Ruth was asleep. I paused, and then turned and draped myself on the doorframe. I stared intently into Elvira's eyes and said with an uncharacteristically large amount of bass in my voice, "I loved you too" (31).

This was an expensive moment onstage. The movements were grand, yet specific. Most importantly, they were justified. My intention was strong and clear. The

\footnotetext{
${ }^{9}$ John Stuart Mill, The Basic Writings of John Stuart Mill (New York: The Modern Library, 2002). 19.
} 
moment was fun to play. Tompkins, along with a supportive cast, had given me the freedom and comfort to explore those boundaries. Now I felt ready for an audience. 


\section{CHAPTER III \\ PERFORMANCE}

\section{Ritual}

When the stage manager calls ten minutes, I lower the lights and close my eyes. I play Pachabel's "Canon in D" softly. The song reminds me of my mother's life. About two minutes into the piece the violins soften and the melody sounds as if it is coming to a close. Just then the strings explode back to life and the tempo picks up. For three more sublime minutes, the violins cry out. Slowly, the music fades away, but never really leaves me.

When I was twelve, my mother was diagnosed with lung cancer and given six months to live. She had surgery, spent a week in intensive care and looked as though she might die. She fought back to life and spent five more years with us before succumbing to the cancer that had metastasized on her brain stem.

The music plays softly and I can picture my mother: her struggle, her triumphant battle, her inevitable death. This is the time when I feel closest to her. This is when I want desperately to believe in an afterlife.

\section{Religion}

The theatre is my church, my sanctuary. Perhaps that is due in part to my introduction to the theatre. After a minor role as Lennox in Macbeth, I got my first lead 
in my second foray onstage. The role was the grouchy, self-centered critic Sheridan Whiteside in Kaufman and Hart's The Man Who Came to Dinner. I was honored to have my first lead so early in my career, especially since this play was co-written by my greatgrandfather, George S. Kaufman. The production took place at my Los Angeles high school, Brentwood School, my senior year.

After a lengthy rehearsal process, the play was set to open on November 18, 1999. That morning, at seven am, I received a phone call from my father. My mother had just died. At seven o'clock that evening I was in my dressing room trying desperately to stop crying so that I could put on make-up. The director told me that we could cancel the show, but I knew better. I went outside to clear my head. I looked to the sky and talked to God, my mom, whomever. 'Mom, I need you now. I don't think I can do this alone. I need your courage, your strength. I need to know you'll be in the wings with me." I waited for something to happen, some sign, some indication that she was there. Nothing. I sighed and said, “Ok mom, I guess I'll have to trust you." I returned to my dressing room and finished preparing.

The curtain went up and I was onstage, performing in a raucous three-act comedy written by my family member on a day of great personal loss. I remembered my mother's last words, which came right after she had watched a taped dress rehearsal of the play. "Jamie," she said quietly, holding my hand and pulling me close to her. "Play for truth, not for laughs, and don't upstage yourself." I remembered her advice. I thought about my familial legacy in the theatre and I performed. I performed and the audience laughed. Their laughter brought me peace. I knew my mother would be proud. In one of my darkest moments, I brought joy and happiness to others. 
During the performance, everything else disappeared. For those two and half hours, my mind was focused exclusively on the play. I had no life outside the theatre. Nothing else mattered. None of the other actors talked to me during intermissions, and I stayed in the zone. The third act came to a close and I had done it.

The curtain call was a series of tableaux with Sheridan and the minor characters. Then the principals walked through the front door to take their bows. Each carried a vibrant Gerber daisy. In turn, each one walked up to me and handed me the flower. Immediately, the tears began to flow. I had told myself that I would not cry onstage, but this touching gesture took me by surprise. I took center stage and bowed.

My performance had not brought my mother back, but I did pay her homage. The weight of my loss was still palpable, but my performance, if only for a short while, served as a testament to her fortitude and grace.

Seven years later, the theatre is still the place where I feel closest to my mother. I do not believe in God. I do not believe in an afterlife. But I do believe in the power of live performance.

I find great comfort and solace in performance and I feel a deep spiritual connection to my family, to my history, and to humanity when I am onstage. I ardently believe in the theatre's power to bond us, to lift us up, and to strengthen and brighten our spirits. Even in the great tragedies, the dark dramas, and the bleak slices of life that we find in much of the dramatic canon, there is a deeper, more interesting revelation of the sameness of our shared struggles. In the torments, the sins, the mistakes, and the anguishes of so many dramatic characters, we are reminded that we are not alone. Our pain is shared, just as our joy so often is. The realization that we are not alone, that our 
struggle, though certainly individual in its detail, smacks of a special universality, this realization has the power to change lives, to comfort those in their darkest hours and provide shelter for those enduring the toughest storms.

\section{The Power of Theatre Realized}

Just six months after my mother died, my father and I saw a production of Margaret Edson's Wit at the Geffen Playhouse in Westwood. Judith Light played the lead, a John Donne scholar diagnosed with fourth stage ovarian cancer. The play examines this strong woman's struggle to come to terms with her own death. Told beautifully by Ms. Edson, an Atlanta schoolteacher and first-time playwright, and performed sublimely by Ms. Light, the performance had a strong impact on my life.

At the end of the play, Ms. Light's character walks downstage left, and after two hours of academic quibbling about punctuation, she decides she finally knows what Donne had written some four hundred years earlier: "Death be not proud; (semicolon) Death, thou shalt die! (exclamation point), ${ }^{10}$ her character declares under a hot spotlight at the lip of the stage. She takes off her bed-gown, exposing her defeated naked flesh and raises her arms triumphantly in the air. The lights fade.

My father and I were in tears. I cried through the entire curtain call and insisted that we stick around to talk with Ms. Light. She came out to the house at our request and I began crying again. "Thank you," I said. "Your performance was so honest and so important to me. My mother died six months ago of cancer and you have done an

${ }^{10}$ Margaret Edson, Wit (Gordonsville, Virginia: Faber and Faber, 1999). 
incredible service to her story," I trailed off as the tears began to flow more rapidly. She took me in her arms and we hugged.

In her honesty and commitment to the character, she paid great tribute to many people who have struggled with death. She exemplified the courage and the resolve that my mother had shown. She captured the fear and anxiety of someone reaching her final days. She embodied the pain and frustration of such a strong woman growing overwhelmingly weak. And in so doing, she gave me the amazing gift of renewed life, of compassion, and of companionship. She reminded me that I am not alone and just knowing that, gives me the strength to endure.

\section{Connection without Tears}

Theatre's power of connection does not always have to be somber. In fact, humor possesses an equally powerful ability to unite and strengthen a community. Laughter is a great equalizer of all humanity. It seems at times that humans are obsessed with labeling. We work tirelessly to divide ourselves, to separate ourselves by lines that we deem important: class, gender, religion, creed, race. These categories have compartmentalized humanity for centuries. Peoples' inability to tolerate such perceived differences has lead to an unthinkable amount of suffering, destruction, and death. But laughter is one of, if not the only thing, that has the power to break through all barriers. When we laugh together, if even for a moment, we unite. We share a common feeling, a similar reaction to a stimulus. Whatever differences people may see in those around them, however isolated or misunderstood they might feel, when everyone laughs, we are one. 
To be able to share that gift as an actor is perhaps what I am most proud of in my life. In a world full of great suffering and overwhelming difficulties, laughter can serve as that momentary respite that gives me the strength to press on, to face the world. I remind myself of this every time I perform and I try to bring that reverence to the stage in every performance, including Blithe Spirit.

\section{Opening Night Rituals}

I always dress up on opening nights. I wake up in the morning and the process begins. It starts with a cup of Earl Grey tea and The New York Times crossword puzzle. Then I take a long, hot shower and put on my sharpest suit. The day goes by, but my focus never wavers. When does the curtain go up?

When I get into the dressing room, I am all business. I listen to music. I put on my makeup. I dress. I always put my shoes on the same way. First my left sock, then my right, then my left shoe, and finally my right shoe. Call it superstition or call it O.C.D., but I have done it consciously before every theatrical and athletic performance of my life since I was thirteen. With so many variables during a performance, it is nice to have these consistencies; this certainty is comforting no matter how minute.

With ten minutes to go, I settle in to my spiritual ritual with Pachabel's "Canon" and before I know it, the stage manager is calling "places." In the production of Blithe Spirit I have an early entrance, so the places call means it is time for me to leave the dressing room. I take one last look at myself in the mirror, checking for the eighteenth time to make sure that my fly is up. I tell Erik DeCicco, who is playing Dr. Bradman, to 
break a leg and give him a hug. Then I walk across the back of the stage to await my entrance.

\section{Curtain}

As the music and lights fade, Ruth makes her entrance and we are under way. I check the prop table repeatedly to make sure that I put my lighter on top of my cigarette case. I double-check that there are cigarettes in the case. Every time I check, I am momentarily relieved, but then feel the need to check again within seconds. Amy Cotteril (Ruth) and Frances Lewis (Edith) finish their short exchange and I make my entrance. I always expect that I will be unable to see the audience, but there they are, clear as day.

I have been onstage numerous times before, but every first entrance elicits nervous pangs. Unfortunately, my first action in this show is to mix cocktails. I am familiar with the task, due in part to much offstage practicing, but the addition of my mildly shaking hands adds new difficulty to the chore. Holding the bottles gives away my shakes, but I do not let it faze me. The lines are coming naturally while my focus is split between listening to Amy Cotteril and not spilling any of the 'gin' as I pour.

The first act moves along handsomely. The Bradmans enter, Madame Arcati enters, and we prepare for the séance. My nerves return since there are several technical components to the séance that were grossly under-rehearsed. During the scene, the table must bang several times, but it must seem as though it comes from someone other than the people sitting around the table. The table was rigged with a pedal similar to a bass drum kick. I was responsible for getting my foot on the pedal and tapping it at the appropriate moments. As we sat around the table, I found my focus increased 
tremendously. I had to split my focus again, this time between everyone's dialogue and deftly moving my foot into place.

The tapping went off without a hitch, but then came time for Jackie Roe's (Elvira) lines over a microphone that had literally been installed that day. She said her first line, but the microphone did not amplify it. For a brief moment, we froze. We had barely heard her. We knew the audience had not. It then occurred to me that it really was not necessary for the audience to hear her since I am supposed to be the only person onstage who hears her anyway. I plowed ahead with my line and we made it out of the scene.

After the séance, I escorted the Bradmans out the front door and then came another tricky bit of staging. I am supposed to reenter after Roe enters and makes her way across the stage, but because of the stage set-up I cannot see her and there is no line to cue my entrance. I listened for footsteps. When they stopped, I assumed I was ready to go. I was wrong. Roe was still downstage left as I entered from upstage right. I immediately turned upstage to the bookcase behind me. Roe pranced around the stage and positioned herself behind me. Cotteril began her lines and the audience believed that I still had not seen Elvira. This was a particularly satisfying stage moment because of the teamwork, trust, and awareness that was required to make the moment work. I had to avert my attention and change the original blocking. Roe had to think and move fast to reposition herself. Cotteril had to hold her line until we were reset without making the audience feel as though something had gone wrong. The transition felt seamless and we saved the payoff for one of my favorite moments in the show.

As the first act comes to a close, Ruth is interrogating Charles who seems quite distracted. I pour myself a drink. As I finish pouring, I look up to see Elvira. I take note 
of her, nod, smile, and take a sip of my drink. As I finish passing by my deceased wife, I do a double take and then my first stage spit-take. What a lovely bit of theatrical cheesiness! The audience ate it up.

Following the spit-take Ruth begins to question Charles's sanity and is inadvertently insulted by her husband who is really yelling at his former wife, the dead one whom only he can see. Throughout the rehearsal process and well into the run, this was a section of dialogue that gave me trouble. Every night, including opening, there seemed to be one line or other that I would jump. Offstage I thanked the women in the scene who had the focus and awareness to catch the leap and cover my error.

In an interesting way, however, it was important for me to have this problem with the script. It humbled me. Several cast members were having line problems, some worse than others, and I think that my own difficulties with memorization kept me from getting overly-frustrated with my fellow cast members. This fostered trust in the company. We were all having problems with the chopped-up text, but we all knew that we could cover each other and make the scenes work.

After the ladies helped cover my line jump, Ruth storms out of the room, furious with Charles. We then share the stage for a short scene to finish the act. As the lights went down, Roe and I soaked up the applause and then walked offstage in the darkness. We squeezed our locked hands tight as we reached the wings. What a rush!

This recapitulation of the first act brings up several interesting insights. First, it illustrates a valuable principle about performance. Sometimes mistakes create the most dynamic moments onstage. When something does not go according to plan, the response to that moment tends to be real. But an actor can only be ready to receive this new 
stimulus if two factors are in place. First, trust has to be present in the company. The group must feel confident enough in each other's skills to make unplanned moments work effectively. It is also imperative that the actors keep their focus outside themselves. Here are some questions specific to Blithe Spirit that facilitated that outward focus: "Why is my wife looking at me like that?" "Should I eat the olive in my martini now?" "Does Dr. Bradman want another drink?" Asking questions that keep the focus external and immediate helps set-up exciting moments. If proper work has been done in the rehearsal hall, the stage becomes the perfect place to explore the true immediacy of every moment. Treating every moment as if it were sacred, observing and responding immediately to the onstage world is ideal. Heightening the sense of awareness to all stimuli helps create a unique, dynamic performance.

Returning to the opening night performance, my entrance at the top of the second act is one of high energy and enthusiasm. Charles is in a great mood. The nerves of the first act give way to excitement. Cotteril and I begin our scene. She skips a section of dialogue. She had done this before. I was ready. I was a little annoyed because I lost a line that I rather liked, but I channeled that energy right into the huge fight about to erupt between us.

The fight was building nicely. We were listening to each other. We were topping each other. It felt good. And then I heard the train. Right in the middle of one of my lines, the train passed behind the building. With a piercing blow the train whistle topped my line. Don't the rail people know there's Art going on in here?!?! No matter though. Tompkins had given us the freedom to comment on the train if we felt the urge. I did not even think about it. I said my line, the train muffled me and I continued speaking 
extemporaneously: "And another thing, darling. I told you that we should have gotten that flat in Essex. That train is abominable!" The line got a huge laugh, but then I caught Ruth's eyes. She did not know what planet she was on, let alone what her next line was. I stopped to think. I could not remember either. I had no idea where we were in the scene. I turned around and walked away. I figured if we were not looking at each other, one of us might find it. There was a moment of extended silence after the laughter subsided, then fortunately Cotteril picked back up. Note to self: In the future, train comments should come at the beginning of a scripted line rather than the end, so as not to change the cue line.

The rest of the second act went smoothly, culminating in Ruth's death. After receiving the news, I froze by the phone as the lights faded. Then I went back to the dressing room for a costume change. DeCicco had to help me affix mourning bands to my jacket. On opening night this took some doing, but by Friday he was a pro with a safety pin. Places were called and I went to the wings. I checked and rechecked my pockets. I need cigarettes to smoke at the top of the act and money to give Edith at the end of the act. Check. Check. House lights are fading, check again. Cigarettes, check. Money, check. Oh God, lighter! Lighter, I need a lighter. Oh, there it is, in my breast pocket. Everything is okay. I take the stage in the darkness. Lights come up on me pouring a drink and the third act begins.

By the time the second scene of the act starts, my character is supposed to be very tired. I was. Though I was riding the high of performance, the evening had been quite exhausting. The second scene flew by. I made a final exit and the lights came down. The audience applauded and we took our bow. And then came the dreaded song. 
Tompkins decided that after the curtain call we would sing Irving Berlin's "Always." Most of us were convinced that by that time in the evening people would just want to leave. But Tompkins insisted and so we formed a tight semi-circle center stage and began the song. The audience stopped applauding and listened. Out of the corner of my eye, I saw an older woman mouthing the words. I felt very connected to her at that moment, not just to her, but to everyone: the audience, the cast, the crew. The song felt good. It felt right. Once again, Tompkins nailed it. We received another warm round of applause after the song ended and headed off stage.

\section{Opening Night Insights}

No one thing contributes to a quality opening night. Like theatre itself, many elements must come together in just the right amount to foster a great first show. Confidence is certainly a factor: Confidence in the director's vision, in the individual performance, and in the work of the ensemble, both cast and crew. This bleeds into the value of trust as well. I cannot overemphasize the value of unity onstage. There is no obstacle too great for a cast and crew that respects each other and looks out for one another.

The best shows are ones in which everyone's attitude is selfless: "My goal onstage is to make my scene partner look good." If that is everyone's mantra, then by law of attraction, everyone looks good and the work feels effortless.

Humility is also of great value to an opening, really to any performance or rehearsal. Patience with those around me creates a supportive atmosphere that is much more conducive to growth and improvement. By remaining humble and supportive in 
every situation, I help strengthen the company and consequently, my performance improves! Alas sometimes this is easier said than done.

While humility is something to work on all the time, opening night nerves are unique to that performance. The nervous energy exists and there is no need to fight it. Instead, work to channel that energy into positives that are useful in performance. A simple breathing exercise may help to center the performer and put him in place to use that nervous energy effectively.

When the process works, it is fun. I was fortunate to be a part of an ensemble that enjoyed the work. This is one of the hardest things to fake onstage. When the performers are having a good time, the audience responds in kind. They are called "plays," after all, and whether the character is dying of AIDS or getting beaten up by a grandmother, the actor can enjoy the moment and love the experience of investing completely in a fictitious world that has the capacity to resonate with so much truth.

It is rewarding and exhilarating when the whole process comes together and the result is a successful evening of theatre. I shared the following words with Professor Tompkins in front of the ensemble after the opening:

Tompkins, there were times in this process that we all wanted to quit. Rehearsals were long and arduous and took a lot out of us. But you saw something in us. You saw the potential to make this production great. You refused to let us settle for anything short of excellence and instilled in us a work ethic that we will take with us long after this play closes. You brought a cast together with extremely varied training and experience levels and you made all the pieces fit into place. Many nights we would 
curse your name during breaks, but tonight we realized your vision. We saw all that hard work pay off, and I must say, it feels damn good to do something well. So thank you for pushing us. I think I speak for the entire cast when I say that we have a great deal of respect for you and, even when you are working us to death, it is a pleasure to be a part of a Jim Tompkins production.

\section{Dead Houses: A Comparison of Two Quieter Audiences}

The energy shifts peculiarly during the second show of a run, particularly with comedies. The biggest stumbling block is that actors expect laughter in the same places they received laughs the night before. The first time an actor takes an unnecessary pause, waiting for a laugh that is not coming, the rhythm of the entire scene gets thrown off and that actor's confidence is shaken.

Our second night was no different. Moments felt forced. Once a few of the lines that had worked the previous night landed flat, confidence sank, self-consciousness set in and the performance suffered.

I remember poking my head into the woman's dressing room after the first act to remind them that just because the audience is not laughing does not mean that they are not enjoying themselves. We have to continue enjoying ourselves and keep driving the action.

Unfortunately, the second act did not go any better. The audience just was not laughing and we all started pushing. Ironically, this created a snowball effect that made the performance choppier and did not help get the audience back into the flow. 
The absence of laughter creates a kind of quicksand effect. The more one struggles to climb out, the deeper one sinks. So it is with the theatre. The harder we tried to get them to laugh, the worse off we became. The more aware we were of their lack of response, the less aware we were of the world of the play. As with quicksand, the best thing to do is simply to relax and wait. In one of my first acting classes with Professor Tompkins, he told us: "Instead of going after the audience, let the audience come after you." " Forcing moments inhibited us from ever riding the performance and allowing the energy and flow of the characters to take us through the story.

But how can we stop ourselves from asking, "why didn’t they laugh at that line? They laughed last night. What did I do differently? Did I screw it up? Was it the inflection? The timing? Was I moving on the line?" Once this happens, there is no return. This kind of thinking traps the actor in the past and does not allow for fresh, spontaneous interactions in the present. As my father used to say when coaching Little League, "don't let one mistake lead to ten others." The Serenity Prayer is also appropriate here: "God grant me the Serenity to accept the things I cannot change, the courage to change the things I can, and the wisdom to know the difference". Whatever the mantra, I think the lesson is to approach each performance with a newness and neutrality. No expectations, no repetitions. Embrace the uniqueness inherent in every performance and avoid comparisons during performance. To borrow an old cliché, one can never place his foot in the river in the same place twice.

This point was clearly illustrated on Saturday night when we faced another quiet audience. After a boisterous show on Friday, this audience shifted the energy in a

${ }^{11}$ James Tompkins, "Acting Pedagogy Class". University of Louisvile. 4 Nov. 2005. 
completely different direction. However, unlike Thursday, we did not allow their calm to bring us down or throw off our rhythm. We did not anticipate any laughs, we picked up cues in the silence and paused for the sporadic laughter. We were aware of what was happening both onstage and in the audience. And we did not let their lack of enthusiasm bring our energy down.

The show was going well. We knew it. Whether the audience agreed or not was of no consequence to us. We were happy with the work and our positive approach helped create an even stronger cohesion and flow.

Though the actor's goal is to move the audience, sometimes it is difficult to tell if this is happening. That is why the actor must make that a secondary concern and focus primarily on giving the strongest performance possible.

\section{Closing Time}

Closings feel bittersweet. On the one hand is a sense of completion, finitude: like driving the last nail into a house or painting the last picket on a fence. On the other hand is a sense of longing and the feeling that with one more week we could explore so much more about the characters. This is particularly true of a show with such a short run, only six performances.

As my high school football coach, Mr. Magier, used to remind us before games, "there should be no celebrating when the game is over because if you have the energy to celebrate, that means you did not leave it all on the field, and that is the only thing that matters." That is exactly how I approach closing night. Some actors play tricks on one another or try ridiculous things onstage, like actors mooning other actors from offstage or 
tampering with costumes, but we put too much into this project to jeopardize it with amateurish stunts and juvenile inside jokes. Fortunately, the rest of the cast shared this sentiment and we gave everything we had for our final performance.

There was still the fear that this performance would have its bumps. In fact, the matinee performance had started quite literally with a crash. Frances Lewis (Edith) was carrying out a tray of cocktail paraphernalia when she tripped on the lip of the stage. The martini shaker went crashing to the ground and olives flew all over the stage. Edith dutifully dusted herself off and cleaned up the mess. It did mean, however, that none of us would have olives in our martinis later.

This may seem like a trivial concern, but for this cast, many had created specific business with the olives. When we chose to eat them, how we played with them in the glass, what we did with the toothpicks afterwards; all these things had been worked out with some detail and precision. But in the afternoon, all this was thrown out the window and the effect was quite fascinating.

The lack of garnish forced me to interact with everyone differently. Every look, every line reading, every gesture, and every movement onstage took on an incredible sense of novelty. Other characters were making subtly different choices as well, and everyone seemed to be more attuned to everyone else.

There was no need to create the "illusion of the first time" as Stanislavski would have us try. This was quite naturally the first time we had done this scene under these circumstances. Although the change was minor, it was enough to create a fresh dynamic onstage and engaged us with each other, our props, and our selves in a new and focused 
way. It was also nice that some of the discoveries that I had made on opening night were finding new applications during our final day.

Instead of worrying about another possible mishap, the cast took the newness the matinee's olive incident created and challenged ourselves to add even more life to the final performance. Lewis stayed on her feet this time and we were off. At the end of the first act, I remember thinking, "I am disappointed that I will not get to perform those scenes again." The second act lights went out and the same thought hit me. As Erik DeCicco was affixing the mourning bands to my jacket for the last time, I could not help but wonder what was so appealing about such an ethereal art form. I like results. I like the tangible, the tactile, the immediate. Theatre is certainly immediate, but it is also fleeting. The connection to the now can be quite strong, yet the state is elusive.

The third act went off without a hitch. I probably took a few seconds longer with my final speech. As I walked offstage, I felt as though I was leaving. More than that, I knew it was over. I was leaving this show behind.

I came out for one final curtain call and was met with the first standing ovation we received during the run. I took one additional bow before holding hands with the cast to take a group bow. Then, still in character, I told the audience to sit back down because "we [were] not quite done yet". Erik DeCicco and I moved the chairs into position for the song and he whistled a "C." We sang with joy in our hearts.

As we finished "Always" for the last time, the audience returned to their feet to send us off. Just as they had seven years ago, tears began to run freely down my cheeks. My time on the University of Louisville's main stage was coming to a close.

I cannot think of a better way to go off. 


\section{Why the Stage?}

When people learn that I grew up in Los Angeles, they find it puzzling that I have moved to Louisville to pursue acting. There are moments when I do too. But then I take the stage and am immediately reminded of the difference between stage and screen acting. The stage offers an intimacy that the screen can never provide. The connection between audience and artist is never more immediate, more powerful, or more visceral than onstage. The storytelling exchange between listener and performer fosters and enhances a deeper, more profound realization of the nature of the human condition. The stories explore people in turmoil. Through laughter and tears, through humor and pathos, the group collectively explores the depths of the human experience and tries in various ways to come to a clearer understanding of what makes us human and what that means.

Of course during performance, the actors cannot actively meditate on these points. They have entrances to make, lines to deliver, blocking to follow, and, most importantly, a sense of truthfulness and playfulness to find with their fellow actors, that they then share with the audience. But in the telling, fueled by both their onstage chemistry and their powerful, psychic connection to the audience, the actors are exploring these questions and offering possible answers to the riddles.

I do not pretend to have the answers myself, but I hope I never stop searching. The theatre feeds my desire to feel, my longing for connection, and my need to seek the Truth.

To quote the dying words of Noel Coward, "Goodnight my darlings. I'll see you tomorrow." I will be in the theatre Noel. I will look for you. 


\section{REFERENCES}

Auburn, David. Proof. Gordonsville, Virginia: Faber and Faber, 2001.

Blithe Spirit. Dir: David Lean. Perf. Rex Harrison, Constance Cummings, Margaret Rutherford, Kay Hammond. Videocassette. United Artists, 1945.

Brecht, Bertolt. Brecht of Theatre: The Development of an Aesthetic. Trans. and Ed. by John Willett. New York: Hill and Wang, 1957.

Cohen, Robert. Acting One. $4^{\text {th }}$ edition. McGraw Hill: Boston, 2002.

Coward, Noel. Blithe Spirit. New York: Samuel French, 1941.

Edson, Margaret. Wit. Gordonsville, Virginia: Faber and Faber, 1999.

Gordon, Mel. Introduction. On the Technique of Acting. New York: Harper Collins, 1991.

Lehman, Rhea. "Blithe Spirit Rehearsal." University of Louisville. 19 Sept. 2006.

Mill, John Stuart. The Basic Writing of John Stuart Mill. New York: The Modern Library, 2002.

Tompkins, James. “Acting Pedagogy Class.” University of Louisvile. 4 Nov. 2005. 


\section{CURRICULUM VITAE}

NAME: James Patrick Cronin

ADDRESS: 1108 Hilliard Ave. \#4

Louisville, KY 40204

DOB: $\quad$ Los Angeles, California - March 28, 1982

EDUCATION

\& TRAINING: $\quad$ B.S., Philosophy \& Speech with a concentration in Theatre East Tennessee State University 2000-2004

TEACHING

EXPERIENCE: Acting for Non-Majors

(University of Louisville, 2005-2007)

Enjoyment of Theatre

(University of Louisville, 2004-2005)

Humor in the Workplace Workshop

(Spalding University, 2006)

AWARDS: $\quad$ Faculty Favorite Award Nomination

(University of Louisville, 2006)

Bud Frank Award for Excellence in Theatre

(East Tennessee State University, 2004)

Presenter, Philosophy Conference

(East Tennessee State University, 2004)

University Honors Scholar

(East Tennessee State University, 2000-2004)

Magna Cum Laude Graduate

(East Tennessee State University, 2004)

Irene Ryan Scholarship Nomation

(East Tennessee State University, 2001, 2002, 2004)

PROFESSIONAL

SOCIETIES:

Screen Actors Guild

(Member in good standing since 1986)

American Federation of Television and Radio Artists

(Member in good standing since 1994) 


\section{CURRICULUM VITAE (cont'd) James Patrick Cronin}

\section{PROFESSIONAL}

SOCIETIES (cont'd): Alpha Psi Omega National Honors Theater Fraternity

(East Tennessee State University 2001-2004)

Sigma Alpha Lambda National Honors Society

(East Tennessee State University 2003-2004)

Phi Kappa Phi Honors Society

(East Tennessee State University \& University of

Louisville 2001-2007)

Golden Key International Honors Society

(East Tennessee State University 2003-2004)

LEADERSHIP

POSITIONS:
Artistic Director, Founder \& Business Manager

The Indicators Improv Troupe (Louisville, 2005-Present)

Co-Founder \& Artistic Director

Patchwork Players Acting Company (Johnson City,

Tennessee, 2002-2004)

Coordinator

Studio Theatre (University of Louisville, 2005-2007)

Event Coordinator

Mother's Love Benefit for the American Cancer Society

Treasurer

(Louisville, March 2006)

Philosophy Club (East Tennessee State University, 2003)

Business Manager

Alpha Psi Omega (East Tennessee State University, 2002)

Campus Liaison

ETSU Democrats (East Tennessee State University, 2004)

\section{WRITING:}

School of Hard Knocks, performed April 2006, University of

Louisville - Studio Theatre (co-writer: Robert Greene)

L'Eggo my Echo!, performed March 2007, University of Louisville

- Studio Theatre (co-writer: Ben Owens)

All My Calling, performed March 2004, East Tennessee State

University - Undergraduate Honors Thesis

Amnesty International, performed April 2004, East Tennessee

State University- Amnesty No Borders Festival 